\title{
Mosquitoes and Culicoides biting midges: vector range and the influence of climate change
}

\author{
A.R.W. Elbers ${ }^{(1) *}$, C.J.M. Koenraadt ${ }^{(2)} \&$ R. Meiswinkel ${ }^{(3)}$ \\ (1) Department of Epidemiology, Crisis Organisation and Diagnostics, Central Veterinary Institute (CVI) \\ of Wageningen UR, P.O. Box 65, 8200 AB Lelystad, the Netherlands \\ (2) Laboratory of Entomology, Wageningen UR, P.O. Box 8031, 6700 EH Wageningen, the Netherlands \\ (3) Via Pratarone 14, Rocca di Cave, 00030 (RM), Italy \\ *Corresponding author: armin.elbers@wur.nl
}

\section{Summary}

Vector-borne animal diseases pose a continuous and substantial threat to livestock economies around the globe. Increasing international travel, the globalisation of trade, and climate change are likely to play a progressively more important role in the introduction, establishment and spread of arthropod-borne pathogens worldwide. A review of the literature reveals that many climatic variables, functioning singly or in combination, exert varying effects on the distribution and range of Culicoides vector midges and mosquitoes. For example, higher temperatures may be associated with increased insect abundance thereby amplifying the risk of disease transmission - but there are no indications yet of dramatic shifts occurring in the geographic range of Culicoides midges. However, the same cannot be said for mosquitoes: over the last few decades, multiple Asian species have established themselves in Europe, spread and are unlikely to ever be eradicated.

Research on how insects respond to changes in climate is still in its infancy. The authors argue that we need to grasp how other annectant changes, such as extremes in precipitation (drought and flooding), may affect the dispersal capability of mosquitoes. Models are useful for assessing the interplay between mosquito vectors expanding their range and the native flora and fauna; however, ecological studies employing classical mark-release-recapture techniques remain essential for addressing fundamental questions about the survival and dispersal of mosquito species, with the resulting parameters fed directly into new-generation disease transmission models. Studies on the eventual impact of mosquitoes on animal and human health should be tackled through large-scale integrated research programmes. Such an approach calls for more collaborative efforts, along the lines of the One Health Initiative.

\section{Keywords}

Aedes - Anopheles - Climate change - Culex - Culicoides imicola - Dispersal - Global warming - Midge - Mosquito - Ochlerotatus - Range expansion - Wind.

\section{Introduction}

Vector-borne animal diseases pose a continuous and substantial threat to livestock economies around the world (1). The indications are that increasing international travel, the globalisation of trade and climate change, among other factors, play an important role in the introduction, establishment and spread of arthropod-borne pathogens (2). In some instances, this is facilitated by the dispersal of vectors over long distances $(>100 \mathrm{~km})$ by prevailing winds (3).
Climate change is defined by the Intergovernmental Panel on Climate Change (IPCC) as a statistically significant variation in either the mean state of the climate or in its variability, persisting for extended periods. Atmospheric observations indicate that, during recent decades, the climate on Earth has changed. According to the report by Working Group I of the IPCC (4), the Earth's surface has become increasingly warmer during each of the last three decades. In addition, in the Northern Hemisphere, the years between 1983 and 2012 marked the warmest 30year period in the last 1,400 years. The globally averaged combined land and ocean surface temperature data show 
a warming of $0.85^{\circ} \mathrm{C}$ over the period 1880 to 2012 ; accordingly, the average temperature is predicted to be 0.3 to $0.7^{\circ} \mathrm{C}$ higher in 2025 , when compared to the average temperature at the end of the 20th Century. Depending on the levels of $\mathrm{CO}_{2}$ concentration in the atmosphere, this increase will range between 0.3 and $4.8^{\circ} \mathrm{C}$ by the end of the 21 st Century. Averaged over the mid-latitude land areas of the Northern Hemisphere, precipitation has increased since 1901. Furthermore, the number of extreme weather events has increased since about 1950 , and it is very probable that, globally, the number of cold days and nights has decreased (meaning that the number of warm days and nights has increased); it is likely that the frequency of heat waves has increased in large parts of Europe, Asia and Australia, as has the area of land affected in regions where most heavy precipitation events occur.

Insects are expected to respond noticeably to climate change because the length of their life cycles is strongly influenced by temperature (5). Changes in the global climate are expected to have a profound impact on arthropod vectors of livestock diseases, altering current distribution patterns and modifying their ability to transmit pathogens (6).

In this review, which deals with vector range in Culicoides midges and mosquitoes, the authors discuss the possible influence of climate change on the mean life span of the vector and its geographic distribution.

\section{Culicoides biting midges}

Culicoides (Diptera: Ceratopogonidae) are small midges (1-3 mm in size), present on all continents except Antarctica, ranging from the tropics to the subtropics, tundra and temperate regions. The males feed on plant sap while the females of nearly all Culicoides species are obligate blood suckers (7). More than 1,450 species have been described and midges clearly recognisable as Culicoides have been found in fossil amber dating back 90 to 100 million years (8). This shows compellingly that Culicoides biting midges have survived and coped with environmental challenges in the past and will probably continue to do so in the future. Worldwide, at least 40 Culicoides species are associated with diseases notifiable to the World Organisation for Animal Health (OIE), such as bluetongue (BT) and African horse sickness, but also with epizootic haemorrhagic disease virus, equine encephalitis virus, Akabane virus, bovine ephemeral fever virus (9) and the recently discovered Schmallenberg virus (10). Besides viruses, other pathogens transmitted by Culicoides midges include bacteria, nematoda and protozoa (9). Insect bite hypersensitivity or 'sweet itch', a common skin disease encountered sporadically in certain horse breeds worldwide, is caused by an allergic reaction to the bites of Culicoides midges (11)

\section{Vector range of Culicoides}

The incursion and spread of vector-transmitted animal and human diseases is caused by the movement of both vectors and hosts. Some vectors, such as mosquitoes and midges, are capable but not very strong fliers, with forward speeds in still air of approximately $0.5 \mathrm{~m} / \mathrm{s}$ (12). In tranquil air, the direction and distance of movement are limited by the vector's ability to find its bearings, and by air speed and flight duration. However, wind induces changes in the direction and distances covered by insects (13).

\section{Short-range dispersal of Culicoides midges}

In the absence of wind or at wind speeds of less than $2 \mathrm{~m} / \mathrm{s}$, insects can fly unaided when seeking shelter, hosts, mates and oviposition sites (12). Insect movement can be divided into station-keeping movements, in which the insect remains within its current habitat, and movements that take it away, permanently or for long periods, from the home patch (14). Station-keeping activity is directed at finding and feeding on hosts, finding shelter, mating and locating breeding habitats. These actions require good track control, and therefore occur within the insect's flight boundary layer (FBL). This is a layer of the atmosphere, usually close to the ground, where the wind speed is so low that the insect can fly in any direction unaided (15).

In the early days of entomological research, the short-range dispersal of Culicoides midges was studied by collecting specimens in the neighbourhood of an isolated breeding site. Whitehead (16) observed that the distribution of C. variipennis extended up to $3.2 \mathrm{~km}$ from an isolated breeding site. Kettle (17) recorded a daily, short-range flight dispersal in C. impunctatus of approximately 70 to $75 \mathrm{~m}$ in the vicinity of its breeding site in Scotland. Dyce (18), Jones and Akey (19) and Zimmerman and Turner (20) observed the flight ranges of C. variipennis in the United States to range between 0.9 and $2 \mathrm{~km}$.

Subsequent mark-release-recapture (MRR) methods have been used to study short-range dispersal in Culicoides midges, incorporating time as an element. In contrast with MRR studies on mosquitoes (see below), the number of studies on midges is very limited. Lillie et al. (21) marked approximately 82,000 individual specimens of $C$. variipennis and found that the mean distances travelled were $0.8 \mathrm{~km}$ on the release night, $2.02 \mathrm{~km}$ one night post release and $2.11 \mathrm{~km}$ two nights post release. The mean distance travelled for all midges recovered (0.49\%) was $1.89 \mathrm{~km}$ up to eight nights post release. Brenner et al. (22) marked 20,646 C. mohave midges released near the Salton Sea Basin in the lower desert of southern California and found that the mean distance travelled by recovered midges was $1.2 \mathrm{~km}$ in the $12 \mathrm{~h}$ post release, and a cumulative distance of $1.94 \mathrm{~km} 30 \mathrm{~h}$ after release. Lillie et al. (23) recovered 
almost $1.5 \%$ of an estimated 40,000 C. mississippiensis, released during two experiments conducted in a salt marsh in Florida, and found the mean distance travelled to range between 2 and $2.5 \mathrm{~km} 24 \mathrm{~h}$ post release. In northern California, Linhares and Anderson (24) found that the maximum distance travelled by marked $C$. variipennis midges was $1.93 \mathrm{~km}$ on the night of release, and $3.05 \mathrm{~km}$ at six days post release.

In a recent study conducted by Kirkeby et al. (25) in Denmark, $0.3 \%$ of the marked Obsoletus group specimens were recovered at the release point on the release night, while eight marked Pulicaris group specimens (1.3\%) were recovered at a maximum distance of $1.75 \mathrm{~km}$.

In conclusion, though the number of studies on short-range dispersal of Culicoides is small, they show that individual midges, within just a few days, are able to traverse distances of up to $5 \mathrm{~km}$. The average flight range is rather similar across species. In contrast, there is much more variation across mosquito species (see below). It is not clear to what extent these local movements depend on wind assistance, but probably not a great deal as, in general, Culicoides become inactive when wind speeds exceed 3 to $4 \mathrm{~km} / \mathrm{h}$. Thus, the flight ranges achieved show Culicoides to be capable flyers, and also that the lure of livestock causes them to disperse quite widely and rapidly within any farming environment.

\section{Long-range dispersal of Culicoides midges}

Long-distance movement is directed at ranging and migration (14). Ranging involves exploring a new area and locating a new home range, and the behaviour stops when this is found. In contrast, the function of migration is to actively relocate the insect to a habitat that is, or will be, better equipped with resources than the present habitat (26). The long-distance movement of insects is most efficiently achieved by utilising the rapid winds situated above the FBL (27). Though the numbers are extremely small, Culicoides midges have been collected at altitudes of up to $300 \mathrm{~m}$ in North America (28), $900 \mathrm{~m}$ in Mexico, 4,000 $\mathrm{m}$ in Louisiana (29) and 2,000 $\mathrm{m}$ in Kenya (30); these observations underpin the assumption that Culicoides are transported over long distances on winds. Insects are cold-blooded and Culicoides midges and mosquitoes are active at temperatures between 10 and $35^{\circ} \mathrm{C}$; therefore, for midges and mosquitoes to survive transportation by winds above the FBL, the winds should be warm: 15 to $20^{\circ} \mathrm{C}$ at night or 20 to $40^{\circ} \mathrm{C}$ by day (31).

The plethora of circumstantial evidence published on the introduction and spread of Culicoides-borne diseases on air streams and the wind over distances of tens (over land) to hundreds of kilometres (mostly over sea) is provided in Table I.
In 1938, a study was executed in which insects were netted weekly at sea from the masts of a number of commercial ships crossing the North Sea from Scotland and England to Germany and Scandinavia (49). Only four Culicoides specimens (C. pulicaris) were netted among 1,825 insects captured during 102 voyages (with a total sailing time of around $1,151 \mathrm{~h}$ ). In an area more than $160 \mathrm{~km}$ from land, catches averaged one insect per hour; in the English Channel, more than $80 \mathrm{~km}$ from the coast, catches averaged four insects per hour. Transport over longer distances is facilitated by the relative smoothness of the sea, while distances covered over land are, on average, shorter because physical barriers may lead to air turbulence, causing the 'drop down' of Culicoides midges (2).

\section{Climatic factors and Culicoides}

Research on how insects respond to changes in climate is still in its infancy. Only 13 years ago, it was concluded that there was no strong evidence to show that climate change was exerting a demonstrable impact on vector-borne diseases, such as malaria, dengue, leishmaniosis and tick-borne diseases (50). In spite of the large amounts of data being gathered, we are still a long way from knowing whether insects and other organisms are responding and adapting to climate change and if such changes apply widely across taxa, space and time (51). The principal difficulty is the absence of long-term (>50 years) data sets, which means that we lack a strong baseline against which to compare and assess species responses to climate change (5). A recent review on climate change and the adaptive response of insects at the margins of their range (52) has provided evidence to show that recent global warming is inducing a poleward shift in the range of certain insects, while other insects are either expanding their range at the high-latitude and high-altitude cool-range margins $(53,54)$ or withdrawing from their lowlatitude and low-altitude warm margins $(55,56)$. However, these conclusions are based upon observations of only a very limited number of insect species.

Wittmann and Baylis (57) provided an excellent overview of the climatic factors (e.g. temperature, precipitation) that can influence distribution, abundance and vectorial capacity in Culicoides. In the main, it would seem clear that, in the future, increased temperatures will lengthen the Culicoides biting season, quicken the larval developmental cycle (thereby increasing the number of generations completed) $(58,59)$ and, importantly, accelerate vector-biting and extrinsic virus replication rates. At the more local farm level, the interplay between climatic and environmental variables (including temperature, relative humidity, light intensity, wind speed and the like) is complex, with changes in optimality from one species to the next. Amongst others, these factors affect abundance, seasonality, fecundity, longevity and vector competency, but our understanding is 
Table I

Studies on the introduction or spread of Culicoides-borne animal diseases by wind

\begin{tabular}{|c|c|c|c|c|c|}
\hline $\begin{array}{l}\text { Vector-borne } \\
\text { disease } \\
\text { or pathogen }\end{array}$ & Year & $\begin{array}{l}\text { Presumed } \\
\text { country of origin }\end{array}$ & Country of destination & $\begin{array}{c}\text { Travel } \\
\text { distance } \\
\text { (in km) }\end{array}$ & Reference \\
\hline Ephemeral fever & 1936 & Australia (Darwin) & Australia (Victoria) & 4,000 & 32 \\
\hline African horse sickness & 1943 & Senegal & Cape Verde Islands & 700 & 33 \\
\hline Ephemeral fever & 1955 & Australia (Kimberley) & Australia (Victoria) & 4,700 & 32 \\
\hline Bluetongue & 1956 & Morocco & Portugal & 50 & 34 \\
\hline African horse sickness & 1960 & Turkey & Cyprus & 120 & 33 \\
\hline Bluetongue & 1964,1966 & Turkey, Syria, Lebanon, Iraq & Israel & $100-1,500$ & 31 \\
\hline African horse sickness & 1966 & Morocco & Spain & 40 & 33 \\
\hline Ephemeral fever & 1967 & Australia (Darwin) & Australia (Victoria) & 4,000 & 32 \\
\hline Thimiri virus & 1974 & Papua New Guinea & Australia (Northern Territories) & 180 & 35 \\
\hline Bluetongue & 1977 & Cyprus & Turkey & 120 & 36 \\
\hline Bluetongue & 1977 & Syria & Cyprus & 200 & 37 \\
\hline Akabane & 1979 & Northern Syria & Turkey & 700 & 36 \\
\hline Bluetongue & 1982 & Cuba & USA & 500 & 38 \\
\hline Akabane & 1983 & Australia & Australia & $130-200$ & 39 \\
\hline EHDV and bluetongue & 1987 & USA & Canada & 130 & 40 \\
\hline Bluetongue & 1988 & USA & Canada & 130 & 40 \\
\hline Bluetongue & 1989 & Australia & Australia & $>200$ & 41 \\
\hline Bluetongue & 1999 & Bulgaria/Turkey & Greece & 130 & 3 \\
\hline Bluetongue & 1999 & Israel & Greece (Island of Rhodes) & 750 & 3 \\
\hline Bluetongue & 2000 & Algeria or Tunisia & Italy (Island of Sardinia) & 225 & 42 \\
\hline Bluetongue & 2000 & Italy (Island of Sardinia) & Spain & 370 & 43 \\
\hline Bluetongue & 2001 & Greece & $\begin{array}{l}\text { Albania, Macedonia, Bulgaria, } \\
\text { Kosovo and Croatia }\end{array}$ & 700 & 3 \\
\hline EHDV & 2006 & Jordan & Israel & 166 & 44 \\
\hline Bluetongue & 2006 & Belgium or the Netherlands & Germany and France & $35-85$ & 2 \\
\hline Bluetongue & 2007 & Belgium & United Kingdom & 130 & 45 \\
\hline Bluetongue & 2007-2008 & Southern Spain & Northern Spain (Basque Country) & 600 & 46 \\
\hline Bluetongue & 2007-2012 & Indonesia, Timor, Papua New Guinea & Australia & $180-1,125$ & 47 \\
\hline Bluetongue & 2008 & Denmark or Germany & Sweden & $350-400$ & 48 \\
\hline
\end{tabular}

EHDV: Epizootic haemorrhagic disease virus

far from complete as most studies have been confined to the laboratory $(60,61,62,63,64)$.

One of the few Culicoides vector species that has been investigated with respect to climate change is C. imicola, long known to be the principal vector for BTV in Africa, the Near and Middle East and in those parts of the Mediterranean region affected before 1998; namely, Israel, Cyprus, Anatolian Turkey, the Greek islands of Rhodes and Lesbos, Morocco, south-western Spain and Portugal (65). Mellor et al. (65) state that C. imicola was absent in many neighbouring areas that had not previously been affected by BTV (Tunisia, northern and eastern parts of Spain, parts of mainland Italy, the islands of Sicily, Sardinia and Corsica, mainland Greece and Bulgaria) but which suddenly, after 1998, were affected by incursions of several serotypes of the virus over successive years. It was argued that these incursions coincided with a marked and durable extension in the northern range limit of the vector $C$. imicola. On a spatio-temporal scale, this phenomenon seemed to correlate with a clear climate change signal, one marked by a significant increase in average temperature over the Mediterranean Basin as a whole (66).

Other investigators $(67,68)$ have, however, remained circumspect about the mooted continuing northward range expansion of $C$. imicola, proposing instead that, in the past, it had simply been overlooked, due to its mosaical distribution and narrow seasonality (August to November), exacerbated by inferior surveillance tools and sporadic, short-term collecting efforts. Indeed, in Italy at least, C. imicola would appear to be in stasis as it has shown no expansion whatsoever in its range since the year 2000, when Italy implemented its large-scale vector surveillance programme, which has been maintained continuously ever since (69). This suggests that, at some point after the last Ice Age, the distribution of $C$. imicola stabilised within the Mediterranean Basin, but remains fragmented and 
constrained due to a preference for planar, low-lying areas, and for soils that are clayey rather than sandy, calcareous, or volcanic in origin.

A recent modelling study (70) indirectly supported the view that $C$. imicola is constrained by its ecology and indicated that there is no evidence to suggest that its range in Spain will expand; nevertheless, it is expected that $C$. imicola will become more abundant in the future, in particular in those south-western areas where it has long been established and where, in all likelihood, it was involved in the large outbreaks of bluetongue that affected the region in the 1950s. A subsequent micro-satellite study (71), conducted on more than 20 populations of C. imicola collected from around the southern and northern shores of the Mediterranean Sea, points unequivocally to its ancient presence within the Basin and suggests that there is longitudinal and ongoing gene flow between the North African and Central Mediterranean populations. Taken together, these factors suggest that causes other than the northward range expansion of C. imicola support the emergence of bluetongue in southern Europe. Winds from North Africa, such as the hot and suffocating south-easterly Sirocco, which blows in from the Sahara, have long existed - indeed, they were named during the time of, and formed part of the mythology of, the ancient Greeks and Romans.

\section{Conclusions: Culicoides midges}

Two principal pathways typify the incursion and spread of Culicoides-borne animal diseases: short (local) and longdistance movements of either the vector or the livestock host; seldom both. At the local level, Culicoides midges are quite able to cover distances of up to $5 \mathrm{~km}$ within just a few days. However, with the help of the wind, they may travel tens to hundreds of kilometres, especially over the sea, to introduce disease into distant areas. In Culicoides, a range of climatic variables acting alone, or in combination, has a profound impact upon distribution, survival and vector competency. Though higher temperatures (within limits) seem inextricably linked to increased risk of transmission, there is no cogent evidence to suggest that vector ranges under the aegis of a warming global climate - are beginning to shift dramatically. In all probability, this is due to many other operational constraints, such as the specialised breeding habitats that differ markedly from one species to the next, including vectors.

What has changed, and cannot be denied, is that, in the last two decades, Culicoides-borne viruses such as bluetongue and Schmallenberg have managed to penetrate higher latitudes than ever before, and that this appears to have occurred at a time when the vector seems to be active for far more of the year or, rather, seems to have quickened its life cycle, completing more generations in a year than the number recorded for the same species in the latter half of the 20th Century. For example, for the first time there is evidence for five to six vector generations being completed in one season in Northern Europe (72). Earlier workers, commencing in the 1940s, reported only one to four generations, and proposed that the exact number was dependent on temperature, so that the number of generations completed varied according to altitude and latitude. Of course, it is now also the case that light-trap collections are for the first time being conducted more systematically and rigorously within parts of Europe, usually weekly at multiple sites and over more than one season, and so the apparent difference between modern and historical data sets on the number of generations completed may yet prove spurious.

Nevertheless, we have become aware that prolonged periods of intense vector activity do occur at higher latitudes. By involving multiple vector species, this magnifies the chance for any virus introduced adventitiously to be acquired by such vectors and subsequently disseminated both widely and rapidly. In Europe, livestock densities are among the highest in the world and yet it remains a puzzle as to why none of the viruses that has made an incursion into Southern or Northern Europe, beginning in 1998, has managed to become permanently established within the region. Whatever the explanation, it is probable that their future endemisation will depend strongly upon an increased 'tropicalisation' of the weather. In other words, a warming climate at more northerly latitudes will enable the vector to remain active for longer, thereby 'creating' a shorter winter which is easier for the virus to survive, an essential step for it to remain in situ and not be forced to 'retreat' into the lowerlatitude tropics from whence it came originally. We have yet to understand whether the recent northward advances of bluetongue and Schmallenberg are a forewarning of more viral incursions to come, and if eventually they will become endemic as the world's climate continues to warm.

\section{Mosquitoes}

\section{Vector range}

Worldwide, more than 3,500 species of mosquitoes (Diptera: Culicidae) have been described (Mosquito Taxonomic Inventory, available at www.mosquito-taxonomic-inventory. info). These can be further classified into 112 genera, four of which contain species that are repeatedly linked with the transmission of disease: Aedes, Anopheles, Culex and Ochlerotatus. Each species has its unique distribution pattern or 'vector range'. Here, the authors define vector range as the geographic area in which individuals of a given vector species can be found and which has clearly demarcated borders or limits. Beyond these borders, the species cannot survive and reproduce but, if it does, these events can be considered novel introductions outside its 
range. Such events could lead to the establishment and further spread of the species (73). Eventually, the species boundaries need to be redefined, which leads to an adjusted or expanded vector range. In this review, the authors focus on how mosquito flight and dispersal affect vector range and how this, in turn, is affected by climate change.

\section{Mosquito dispersal}

Although the term 'range' is synonymous with 'distribution', the authors prefer the former, because of its close link with 'range expansion', a common term in biogeography (74). Dispersal is a key ecological phenomenon that underlies vector range. It is an adaptive part of the life history of every species and can be defined as the capacity to move from birthplaces to new sites (74).

Mosquito larvae occur in a wide range of aquatic habitats, such as domestic water storage jars (e.g. the yellow fever mosquito Ae. aegypti); sun-exposed, ephemeral water puddles (e.g. the malaria vector An. coluzzii [formerly An. Gambiae]); wastewater cesspits (the West Nile virus vector Culex pipiens); and flood plains (Oc. sticticus, mostly a nuisance species) (75). The availability and abundance of these sites have a strong influence on the distance that individual adult female mosquitoes need to fly in order to lay their eggs. For this purpose, the females first need to find a mate and a blood meal. The availability and distribution of blood hosts is also an important determinant of the daily flight range of mosquitoes. In addition, adult mosquitoes need suitable resting sites and nectar sources in their vicinity, to be able to shelter from adverse weather conditions and predation, and to replenish their energy reserves. All these requirements taken together shape the ecological niche occupied by each individual species (see also the section on niche modelling, in 'Modelling vector range and the impact of climate change', below). As a consequence, some species can be classified as weak fliers because of their limited need to fly far, whereas others can be classified as strong fliers (75). These typical niches can be linked with landscape type. For example, weak fliers are often found in urban domestic and in-forest environments, weak to moderate flyers occur in woodlands, and strong fliers can be found in more open areas (76).

\section{Long-range dispersal}

The dispersal of adult mosquitoes can be classified into longand short-range dispersal $(77,78)$. Long-range dispersal is often unintentional and aided by wind or human transport, e.g. with the shipment of goods and passenger flights. The distances between origin and destination can be hundreds of kilometres apart. Often such events are survived by a few specimens only and do not create nuisance situations. Long-range dispersal is considered a passive, accidental activity that results from strong winds that carry swarms of mosquitoes downwind. Interestingly, some species have been observed to actively take off shortly after emergence and fly up into the air at a steep angle until they reach a height of approximately $12 \mathrm{~m}$, from where they can be further transported by the wind. Whether this is truly intentional or adaptive remains unclear $(79,80)$. In addition, a massive displacement of the flood plain mosquito, Ae. vexans, has led to the largest dispersal distance on record; namely, an estimated $370 \mathrm{~km}$ (81). This displacement was associated with the invasion of a massive cold air front after a heat wave from an area that had large populations of this nuisance biting mosquito (Wisconsin) into an area that is not known for this species (Chicago, Illinois).

In contrast with the Culicoides species (Table I), introductions of mosquito-borne diseases into novel areas have not been associated with wind-related mosquito displacement or dispersal. However, for Rift Valley fever outbreaks in Egypt and South Africa, the possibility of windborne introduction is considered likely, since other possible introduction scenarios have largely been excluded $(82,83)$.

Next to windborne displacement, the transport of Plasmodium-infected Anopheles mosquitoes on board aircraft is a cause of airport malaria throughout the world $(84,85)$. The tremendous global connectivity and rapid rise in new connections between endemic and disease-free areas is of great concern for the spread of vector-borne diseases. Initiatives are under way to assess the likely impact and to design timely intervention strategies, such as, for example, the online Vector-borne Disease Air Importation Risk tool (86).

\section{Short-range dispersal}

On the other hand, short-range dispersal is often intentional. It can be further divided into non-oriented flight or flight oriented towards host location and attraction (78). The last two types of dispersal are associated with host-seeking mosquitoes and are mediated by host-derived cues, such as odours (lactic acid, ammonia, fatty acids, $\mathrm{CO}_{2}$ ), as well as humidity and (body) heat $(87,88)$. This dispersal eventually results in a blood meal.

The aim of non-oriented flights is to increase the actual likelihood of encountering a host. This is speciesdependent, but also strongly influenced by the environment and thus sensitive to environmental change. Temperature, humidity, illumination, wind and local topography are key environmental determinants of non-oriented short-range dispersal. When temperatures drop below $16^{\circ} \mathrm{C}$, drastic reductions in mosquito catches have been observed (89). Moonlit nights are known to enable us to collect larger numbers of mosquitoes than moonless nights. Most likely, because the light intensity of the full moon is close to the level at twilight, mosquitoes remain actively flying (89). Intrinsic 
drivers of non-oriented flight include the physiological status of the mosquito, such as egg maturation, mating status and energy balance $(79,80)$.

Having reliable estimates of mosquito dispersal distance is essential for determining the medical and veterinary impact of this group of insects. First, large populations of mosquitoes can lead to nuisances, mostly in the form of annoying bites. The general public often associates such large populations with (re)wetted and newly constructed wetlands, and so there is a need to inform wetland managers and policy-makers with solid evidence of the required width of barrier zones between housing and mosquito-breeding areas, to protect people from nuisance situations. A recent meta-data analysis of 460 articles on this topic studied the maximum flight distance of 105 species of mosquito. It was concluded that average flight distances are comparable among mosquito genera, with recorded average maximum distances of $3 \mathrm{~km}$ for Aedes, $3.5 \mathrm{~km}$ for Anopheles, $5 \mathrm{~km}$ for Culex and $7.6 \mathrm{~km}$ for Ochlerotatus (76). Nevertheless, there are large variations within these genera. Some species, such as Ae. polynesiensis, Ae. scutellaris and Oc. rusticus, have a very weak dispersal capacity (50-100 m), whereas others are known as strong dispersers, e.g. Oc. taeniorhynchus $(32 \mathrm{~km})$, An. freeborni $(35 \mathrm{~km})$, Ae cantator $(48 \mathrm{~km})$ and Ae. sollicitans $(48 \mathrm{~km})(76)$.

Besides its importance in establishing barrier zones to prevent mosquito nuisance, mosquito dispersal is also an important driver of the spread of human and animal diseases transmitted by these insects. Some of these diseases are of special concern as they are re-emerging or emerging in areas where the disease was not known previously. In the framework of the One Health approach, which aims to unify medical and veterinary science, mosquitoes can act as bridge vectors of zoonotic pathogens. The capability of mosquitoes to cover distances between animal (wildlife and livestock) and human populations is therefore crucial in assessing human health risks. Recently, an authoritative assembly of mosquito MRR studies has been made available. This database contains 774 unique MRR studies and aims to better inform basic research and public health interventions (90). Mark-release-recapture studies are considered the method of choice for estimating population size and mosquito survival as well as dispersal, and the first of these studies dates back to the early 20th Century (91). Various methods for marking mosquitoes are available, including tags, dye, dust, (radioactive) isotopes and proteins. In general, such methods have little adverse effect on the released organisms, although careful consideration should be given not only to the direct impact on survival, but also on (host-seeking) behaviours (92). A major limitation of such studies is often the very low recapture rate. For example, in one study, despite capturing and releasing several tens of thousands of Ae. vexans and Oc. sticticus, only 22 marked mosquitoes were recaptured (93).

\section{Modelling vector range and the impact of climate change}

Climate change facilitates shifts in the range of animal and plant species, especially across latitudes and altitudes (73). A meta-analysis of several animal and plant taxa revealed that the average latitudinal shift is $16.9 \mathrm{~km}$ per decade, whereas the average altitudinal shift is $11 \mathrm{~m}$ per decade (94). Both range shifts are more pronounced when the climate warms more quickly. Although these data are available and have been analysed for several insect taxa, such as butterflies, beetles and grasshoppers, they lack mosquitoes as a taxon. Nevertheless, it is likely that climate warming similarly affects the range of mosquito species. It is predicted that the actual direction and rate of this expansion strongly depends on the size of the initial founder population ("propagule pressure'), as well as on its interactions with the native mosquito community and other members of the food web $(95,96)$; as, for example, demonstrated by the invasion of Ae. albopictus into Florida (97).

The current range or distribution of a mosquito species is often derived from data on its presence or absence. Plotting such points on a map gives an idea of the total area in which the species can be found. Based on expert opinion, extrapolations can be made for areas that are underrepresented in this sample or which were not sampled at all. Now that geographic information system (GIS) tools have become widely available, more precise correlations between presence/absence records and environmental parameters can be made. Such approaches aim to model the ecological niche that a species occupies, which can be defined as the multidimensional set of conditions that define the ecological space occupied by a particular species. In some instances, such models are based on climatic parameters, such as average January temperature and annual precipitation (e.g. for the Asian tiger mosquito, Ae. albopictus) (98), whereas other models use more advanced statistical approaches for modelling the same species (99). Because absence data are not always available, new modelling techniques, such as Maxent software, employ only presence data and perform equally well as, if not better than, previous models (100). For example, this approach was used to model the distributions of Ae. aegypti and Cx. pipiens as potential vectors of Rift Valley fever. It revealed essential knowledge for planning and rolling out disease control strategies and discovering previously unknown risk areas (101). Once such niche models are available, they can be run in parallel with climate-change scenarios, to assess the impact of climate change on the geographic range of the species and the associated health risk. CLIMEX software was specifically developed to understand the impact of climate change on species distribution. It has been used to model the potential range expansion of African anophelines and the invasion of Ae. albopictus into Australia $(102,103)$. 
However, we should keep in mind that range expansions can indeed lead to biological invasions into new areas, but that ecological interactions with newly encountered species can also be modified by factors other than temperature, such as photoperiodism (104). In general, northward expansions are less likely to be successful, as these require adaptations to cope with more extreme seasonality in day length and light quality. Invasions from North America into Europe are thought to be less common than the reverse, because of the larger seasonal and photoperiodic variations in European areas with comparable climate zones (104).

It should be noted that most research on the impact of climate change on mosquito biology and mosquitoborne disease focuses on the effects of temperature and fluctuations within temperature $(105,106)$. It is clear that rainfall patterns may also drastically change in the next few decades, with an expected increase in the contrast between wet and dry regions and between wet and dry seasons (4). Although water is a prerequisite for female mosquitoes to lay their eggs, increases in rainfall do not necessarily translate into larger populations of mosquitoes (e.g. mosquito larvae and pupae may be flushed out of their habitats) (107) and thus altered risks of mosquito-borne disease transmission. For example, outbreaks of West Nile virus can be driven by extensive droughts in spring, followed by summer rainfall (108), whereas outbreaks of Rift Valley fever follow heavy rainfall events that are conducive to the massive breeding of flood plain mosquitoes, such as Ae. vexans (109). In conclusion, rainfall and humidity have a direct impact on the dispersal of mosquito populations since they can determine a mosquito's decision to take flight or not. These parameters also affect local survival in new territories (colonisation and extinction) and thus the possibilities for range expansion.

\section{Conclusions: mosquitoes}

It is clear that mosquito dispersal plays a crucial role in determining the current range of mosquitoes and that climate is an important, extrinsic driver of the mosquito to initiate flight. This is evidenced by the numerous classical papers on mosquito dispersal dating back to the early 20th
Century, but also by recent concerns that vectors are now appearing in areas where they have not occurred before. Such invasions are most likely an interplay of natural processes, such as colonisation and survival, that are driven by climate change, together with human-aided transport mechanisms. The authors argue that we must understand changes other than those of temperature alone, such as how more extreme patterns in precipitation (drought and flooding) affect the dispersal capability of mosquitoes. Global-scale models, as well as finer-scaled niche models, have proven useful tools in assessing the interplay between vectors that are expanding their range and native flora and fauna. Ecological studies that use classical MRR techniques remain essential to address fundamental questions about the survival and dispersal of mosquito species. The resulting parameters can directly feed into disease transmission models. The eventual impact on the risk to animal and human health should be tackled through integrated research and this calls for more collaborative efforts along the lines of the One Health Initiative.

\section{Acknowledgements}

Armin Elbers and Sander Koenraadt contributed equally to the body of work of this manuscript: Armin Elbers to the introduction and the section on Culicoides and Sander Koenraadt to the section on mosquitoes. Rudy Meiswinkel edited and added substantial content to the draft version of the Culicoides portion of the manuscript. This study was supported by the Dutch Ministry of Economic Affairs (Veterinary Epidemiology and Risk Analysis Project WOT01-001-004). 


\title{
Les moustiques et les moucherons piqueurs Culicoides : diversité des vecteurs et influence du changement climatique
}

\author{
A.R.W. Elbers, C.J.M. Koenraadt \& R. Meiswinkel
}

\section{Résumé}

Les maladies animales à transmission vectorielle représentent une menace majeure persistante pour l'économie de l'élevage dans le monde entier. L'intensification des déplacements internationaux, la mondialisation des échanges et les changements climatiques jouent probablement un rôle de plus en plus important dans l'introduction, l'installation et la propagation des agents pathogènes transmis par des arthropodes dans le monde. L'analyse de la littérature fait ressortir les nombreuses variables climatiques qui exercent isolément ou conjointement des effets protéiformes sur la distribution et la diversité des moustiques et des moucherons du genre Culicoides vecteurs de maladies. Par exemple, la hausse des températures a pu être associée à une augmentation des populations d'insectes, ce qui accroît également le risque de transmission de maladies ; toutefois, il n'y a pas encore de signes manifestes d'un changement drastique de la distribution géographique des moucherons du genre Culicoides. II n'en va pas de même avec les moustiques : en effet, depuis quelques décennies, de nombreuses espèces asiatiques se sont établies en Europe, où elles se propagent sans que leur éradication paraisse envisageable. La recherche sur la manière dont les insectes s'adaptent au changement climatique est une discipline naissante. Les auteurs recommandent de prendre en compte d'autres changements pertinents, par exemple les évènements pluviométriques extrêmes (sécheresse et inondations) susceptibles d'affecter les capacités de dispersion des moustiques. L'utilisation de modèles permet d'apprécier les interactions entre la diversité accrue des vecteurs, d'une part, et la flore et la faune natives, d'autre part ; néanmoins, les études écologiques basées sur les protocoles traditionnels de marquage/remise en liberté/recapture demeurent incontournables pour répondre à des questions fondamentales sur la survie et la distribution des espèces de moustiques tout en mettant en lumière des paramètres qui peuvent être directement intégrés dans les modèles de nouvelle génération décrivant la transmission des maladies. Les études sur l'impact éventuel des moustiques sur la santé animale et humaine doivent être soutenues par des programmes de recherche intégrée à grande échelle. Une telle approche exige des efforts de nature plus collaborative, en phase avec l'initiative "Une seule santé $"$.

\section{Mots-clés}

Aedes - Anopheles - Changement climatique - Culex - Culicoides imicola - Dispersion - Diversification - Moucheron - Moustique - Ochlerotatus - Réchauffement climatique - Vent. 


\title{
Mosquitos y jejenes Culicoides: distribución de los vectores e influencia del cambio climático
}

\author{
A.R.W. Elbers, C.J.M. Koenraadt \& R. Meiswinkel
}

\section{Resumen}

Las enfermedades animales transmitidas por vectores suponen una importante y constante amenaza para la economía ganadera en el mundo entero. Es probable que el auge de los viajes internacionales, la mundialización del comercio y el cambio climático ejerzan una influencia cada vez mayor en la introducción, el asentamiento y la propagación por doquier de patógenos transmitidos por artrópodos. El examen de la bibliografía existente pone de manifiesto que muchas variables climáticas, solas o combinadas, ejercen efectos diversos sobre la distribución y el radio de acción de mosquitos y jejenes del género Culicoides que actúan como vectores. Un aumento de las temperaturas, por ejemplo, puede traer consigo una mayor abundancia de insectos (lo que acrecienta el riesgo de transmisión de enfermedades), aunque todavía no hay indicios de que la distribución geográfica de los jejenes Culicoides esté experimentando cambios notables. No cabe decir otro tanto, sin embargo, de los mosquitos: en los últimos decenios varias especies asiáticas se han asentado y diseminado en Europa, y ahora es improbable que alguna día se logre erradicarlas.

La investigación sobre la respuesta de los insectos a las alteraciones del clima está todavía en sus balbuceos. Los autores afirman que debemos entender el modo en que otros cambios conexos, como los valores extremos de precipitaciones (sequías e inundaciones), pueden afectar a la capacidad de dispersión de los mosquitos. Los modelos son útiles para estudiar la influencia recíproca entre el aumento del área de distribución de los mosquitos y la flora y fauna autóctonas. Sin embargo, los estudios ecológicos basados en las técnicas de marca, liberación y recaptura de animales siguen siendo básicos para abordar interrogantes fundamentales sobre la supervivencia y dispersión de las especies de mosquito e introducir directamente los parámetros resultantes de esos estudios en los modelos de nueva generación sobre la transmisión de enfermedades. El estudio del impacto final de los mosquitos sobre la salud animal y humana debe abordarse con programas de investigación integrada a gran escala, lo que a su vez exige labores más coordinadas, en la línea de la iniciativa «Una sola salud».

\section{Palabras clave}

Aedes - Anopheles - Calentamiento planetario - Cambio climático - Culex - Culicoides imicola - Dispersión - Expansión del área de distribución - Jején - Mosquito Ochlerotatus - Viento. 


\section{References}

1. World Health Organization (WHO) (2000). - World health report 2000. Health systems: improving performance. WHO, Geneva.

2. Hendrickx G., Gilbert M., Staubach C., Elbers A., Mintiens K., Gerbier G. \& Ducheyne E. (2008). - A wind density model to quantify the airborne spread of Culicoides species during north-western Europe bluetongue epidemic, 2006. Prev. Vet. Med., 87, 162-181. doi:10.1016/j.prevetmed.2008.06.009.

3. Ducheyne E., De Deken R., Becu S., Codina B., Nomikou K., Mangana-Vougiaki O., Georgiev G., Purse B.V. \& Hendrickx G. (2007). - Quantifying the wind dispersal of Culicoides species in Greece and Bulgaria. Geospat. Hlth, 2, 177-189.

4. Intergovernmental Panel on Climate Change (IPCC) (2013). - Climate Change 2013: the physical science basis. Contribution of Working Group I to the 5th assessment report of the IPCC (T.F. Stocker, D. Qin, G.-K. Plattner, M. Tignor, S.K. Allen, J. Boschung, A. Nauels, Y. Xia, V. Bex \& P.M. Midgley, eds). Cambridge University Press, Cambridge \& New York, 1535 pp.

5. Wilson R.J. \& Maclean I.M.D. (2011). - Recent evidence for the climate change threat to Lepidoptera and other insects. J. Insect Conserv., 15, 259-268.

6. Tabachnick W.J. (2010). - Challenges in predicting climate and environmental effects on vector-borne disease episystems in a changing world. J. Experim. Biol., 213, 946-954.

7. Meiswinkel R., Venter G.J. \& Nevill E.M. (2004). Vectors: Culicoides spp. In Infectious diseases of livestock (J.A.W. Coetzer \& R.C. Tustin, eds), 2nd Ed., Vol. I. Oxford University Press, Capetown, South Africa, 93-136.

8. Borkent A. (1996). - Biting midges from Upper Cretaceous New Jersey amber (Diptera: Ceratopogonidae). Am. Museum Novitates, 3159, 1-29.

9. Mellor P.S., Boorman J. \& Baylis M. (2000). - Culicoides biting midges: their role as arbovirus vectors. Annu. Rev. Entomol., 45, 307-340

10. Elbers A.R.W., Meiswinkel R., van Weezep E., Sloet van Oldruitenborgh-Oosterbaan M.M. \& Kooi E.A. (2013). - Schmallenberg virus detected by RT-PCR in Culicoides biting midges captured during the 2011 epidemic in the Netherlands. Emerg. Infect. Dis., 19, 106-109.

11. Anderson G.S., Belton P. \& Kleider N. (1988). - The hypersensitivity of horses to Culicoides bites in British Columbia. Can. Vet. J., 29, 718-723.

12. Sellers R.F. (1980). - Weather, host and vector: their interplay in the spread of insect-borne animal virus diseases. J. Hyg. (Camb.), 85, 65-102.
13. Pedgley D.E. (1983). - Windborne spread of insect-transmitted diseases of animals and man. Philos. Trans. Roy. Soc. Lond., B, Biol. Sci., 302, 463-470.

14. Chapman J.S., Drake V.A. \& Reynolds D.R. (2011). - Recent insights from radar studies of insect flight. Annu. Rev. Entomol., $56,337-356$

15. Taylor L.R. (1974). - Insect migration, flight periodicity and the boundary layer. J. Anim. Ecol., 43, 225-238.

16. Whitehead F.E. (1935). - Damage to livestock by blood sucking midges. Rep. Oklahoma Agric. Exp. Stn, 1932-1934, 264-268.

17. Kettle D.S. (1951). - The spatial distribution of Culicoides impunctatus Goeth. under woodland and moorland conditions and its flight range through woodland. Bull. Entomol. Res., 42, 239-291

18. Dyce A.L. (1969). - The recognition of nulliparous and parous Culicoides (Diptera: Ceratopogonidae) without dissection. J. Aust. Entomol. Soc., 8, 11-15.

19. Jones R.H. \& Akey D.H. (1977). - Biting flies attacking Holstein cattle in a bluetongue enzootic area in Colorado, 1976. Mosq. News, 37 (3), 372-376.

20. Zimmerman R.H. \& Turner E.C. (1984). - Dispersal and gonotrophic age of Culicoides variipennis (Diptera: Ceratopogonidae) at an isolated site in southwestern Virginia, USA. J. Med. Entomol., 21 (5), 527-535.

21. Lillie T.H., Marquardt W.C. \& Jones R.H. (1981). - The flight range of Culicoides variipennis (Diptera: Ceratopogonidae). Can. Entomol., 113, 419-426.

22. Brenner R.J., Wargo M.J., Stains G.S. \& Mulla M.S. (1984). The dispersal of Culicoides mohave (Diptera: Ceratopogonidae) in the desert of southern California. Mosq. News, 44, 343-350.

23. Lillie T.H., Kline D.L. \& Hall D.W. (1985). - The dispersal of Culicoides mississippiensis (Diptera: Ceratopogonidae) in a salt marsh near Yankeetown, Florida. J. Am. Mosq. Control Assoc., 1 (4), 463-467.

24. Linhares A.X. \& Anderson J.R. (1989). - Dispersal of natural populations of Culicoides variipennis (Coquillett) (Diptera: Ceratopogonidae) in northern California. Bull. Soc. Vect. Ecol., 14 (2), 336-346.

25. Kirkeby C., Bodker R., Stockmarr A., Lind P. \& Heegaard P.M.H. (2013). - Quantifying dispersal of European Culicoides (Diptera: Ceratopogonidae) vectors between farms using a novel mark-release-recapture technique. PLoS ONE, 8 (4), e61269.

26. Reynolds D.R., Chapman J.W. \& Harrington R. (2006). - The migration of insect vectors of plant and animal viruses. Adv. Virus Res., 67, 453-517. 
27. Drake V.A. \& Farrow R.A. (1988). - The influence of atmospheric structure and motions on insect migration. Annu. Rev. Entomol., 33, 183-210.

28. Glick P.A. \& Noble L.W. (1961). - Airborne movement of the pink bollworm and other arthropods. USDA Tech. Bull., 1255, 20 pp.

29. Glick P.A. (1939). - The distribution of insects, spiders and mites in the air. USDA Tech. Bull., 673, 151 pp.

30. Linthicum K.J. \& Davies F.G. (1984). - Aerial collection of Culicoides schultzei group (Diptera: Ceratopogonidae) in Kenya. Mosq. News, 44 (4), 601-603.

31. Braverman Y. \& Chechik F. (1996). - Air streams and the introduction of animal diseases borne on Culicoides (Diptera: Ceratopogonidae) into Israel. Rev. Sci. Tech. Off. Int. Epiz., 15 (3), 1037-1052.

32. Murray M.D. (1970). - The spread of ephemeral fever of cattle during the 1967-68 epizootic in Australia. Aust. Vet. J., $46,77-82$.

33. Sellers R.F., Pedgley D.E. \& Tucker M.R. (1977). - Possible spread of African horse sickness on the wind. J. Hyg. (Camb.), 79, 279-298.

34. Sellers R.F., Pedgley D.E. \& Tucker M.R. (1978). - Possible windborne spread of bluetongue to Portugal, June-July 1956. J. Hyg. (Camb.), 81, 189-196.

35. Standfast H.A. \& Dyce A.L. (1982). - Isolation of Thimiri virus from Culicoides histrio (Diptera: Ceratopogonidae) collected in northern Australia. J. Med. Entomol., 19, 212.

36. Sellers R.F. \& Pedgley D.E. (1985). - Possible windborne spread to western Turkey of bluetongue virus in 1977 and of Akabane virus in 1979. J. Hyg. (Camb.), 95, 149-158.

37. Sellers R.F., Gibbs E.P.J., Herniman K.A.J., Pedgley D.E. \& Tucker M.R. (1979). - Possible origin of the bluetongue epidemic in Cyprus, August 1977. J. Hyg. (Camb.), 83, 547-555

38. Sellers R.F. \& Maarouf A.R. (1989). - Trajectory analysis and bluetongue virus serotype 2 in Florida 1982. Can. J. Vet. Res., 53, 100-102

39. Murray M.D. (1987). - Akabane epizootics in New South Wales: evidence for long-distance dispersal of the biting midge Culicoides brevitarsis. Aust. Vet. J., 64 (10), 305-308.

40. Sellers R.F. \& Maarouf A.R. (1991). - Possible introduction of epizootic hemorrhagic disease of deer virus (serotype 2) and bluetongue virus (serotype 11) into British Columbia in 1987 and 1988 by infected Culicoides carried on the wind. Can. J. Vet. Res., 55 (4), 367-370.

41. Murray M.D. \& Kirkland P.D. (1995). - Bluetongue and Douglas virus activity in New South Wales in 1989: further evidence for long-distance dispersal of the biting midge Culicoides brevitarsis. Aust. Vet. J., 72 (2), 56-57.
42. Calistri P., Giovannini A., Conte A., Nannini D., Santucci U., Patta C., Rolesu S. \& Caporale V. (2004). - Bluetongue in Italy: Part I. Vet. Ital., 40 (3), 243-251.

43. Alba A., Casal J. \& Domingo M. (2004). - Possible introduction of bluetongue into the Balearic Islands, Spain, in 2000, via air streams. Vet. Rec., 155, 460-461.

44. Kedmi M., Herziger Y., Galon N., Cohen R.M., Perel M., Batten C., Braverman Y., Gottlieb Y., Shpigel N. \& Klement E. (2010). - The association of winds with the spread of EHDV in dairy cattle in Israel during an outbreak in 2006. Prev. Vet. Med., 96, 152-160.

45. Gloster J., Burgin L., Witham C., Athanassiadou M. \& Mellor P.S. (2008). - Bluetongue in the United Kingdom and Northern Europe in 2007 and key issues for 2008. Vet. Rec., $162,298-302$

46. García-Lastra R., Leginagoikoa I., Plazaola J.M., Ocabo B., Aduriz G., Nunes T. \& Juste R.A. (2012). Bluetongue virus serotype 1 outbreak in the Basque Country (northern Spain) 2007-2008. Data support a primary vector windborne transport. PLoS ONE, 7, e34421.

47. Eagles D., Melville L., Weir R., Davis S., Bellis G., Zalucki M., Walker P. \& Durr P. (2014). - Long-distance aerial dispersal of Culicoides biting midges: case studies of incursions into Australia. BMC Vet. Res., 10, 135. doi:10.1186/17466148-10-135.

48. Agren E.C.C., Burgin L., Sternberg Lewerin S., Gloster J. \& Elvander M. (2010). - Possible means of introduction of bluetongue virus serotype 8 to Sweden in August 2008: comparison of results from two models for atmospheric transport of the Culicoides vector. Vet. Rec., $167,484-488$

49. Hardy A.C. \& Cheng L. (1986). - Studies in the distribution of insects by aerial currents. III. Insect drift over the sea. Ecol. Entomol., 11, 283-290.

50. Kovats R.S., Campbell-Lendrum D.H., McMichael A.J., Woodward A. \& Cox J.St.H. (2001). - Early effects of climate change: do they include changes in vector-borne disease? Philos. Trans. Roy. Soc. Lond., B, Biol. Sci., 356, 1057-1068.

51. Andrew N.G., Hill S.J., Binns M., Bahar M.H., Ridley E.V., Jung M.-P., Fyfe C., Yates M. \& Khusro M. (2013). - Assessing insect responses to climate change: what are we testing for? where should we be heading? Peer J., 1, el1. doi:10.7717/ peerj.11.

52. Hill J.K., Griffiths H.M. \& Thomas C.D. (2011). - Climate change and evolutionary adaptations at species' range margins. Annu. Rev. Entomol., 56, 143-159.

53. Hickling R., Roy D.B., Hill J.K., Fox R. \& Thomas C.D. (2006). - The distributions of a wide range of taxonomic groups are expanding polewards. Glob. Change Biol., 12, 450-455. 
54. Parmesan C. \& Yohe G. (2003). - A globally coherent fingerprint of climate change impacts across natural systems. Nature, 421, 37-42.

55. Franco A.M.A., Will J.K., Kitschke C., Collingham Y.C., Roy D.B., Fox R., Huntley B. \& Thomas C.D. (2006). Impacts of climate warming and habitat loss on extinctions at species' low-latitude range boundaries. Glob. Change Biol., 12, 1545-1553.

56. Parmesan C. (1996). - Climate and species' range. Nature, 382, 765-766

57. Wittmann E.J. \& Baylis M. (2000). - Climate change: effects on Culicoides-transmitted viruses and implications for the UK. Vet. J., 160, 107-117.

58. Bishop A.L., McKenzie H.J., Barchia I.M. \& Harris A.M. (1996). - Effect of temperature regimes on the development, survival and emergence of Culicoides brevitarsis Kieffer (Diptera: Ceratopogonidae). Aust. J. Entomol., 35, 261-368.

59. Vaughan J.A. \& Turner E.C. (1987). - Development of immature Culicoides variipennis (Diptera: Ceratopogonidae) from Saltville, Virginia, at constant laboratory temperatures. J. Med. Entomol., 24, 390-395.

60. Hunt G.J., Tabachnick W.J. \& McKinnon C.N. (1989). Environmental factors affecting mortality of adult Culicoides variipennis (Diptera: Ceratopogonidae) in the laboratory. J. Am. Mosq. Control Assoc., 5, 387-391.

61. Kramer W.L., Greiner E.C. \& Gibbs E.P.J. (1985). - Seasonal variations in population size, fecundity and parity rate of Culicoides insignis (Diptera: Ceratopogonidae) in Florida, USA. J. Med. Entomol., 22, 163-169.

62. Murray M.D. (1991). - The seasonal abundance of female biting midges, Culicoides brevitarsis Kieffer (Diptera: Ceratopogonidae), in coastal south-eastern Australia. Aust. J. Zool., 39, 333-342.

63. Rawlings P., Capela R., Pro M.J., Ortega M.D., Pena I., Rubio C., Gasca A. \& Mellor P.S. (1998). - The relationship between climate and the distribution of Culicoides imicola in Iberia. Arch. Virol. Suppl., 14, 93-102.

64. Wittmann E.J., Mellor P.S. \& Baylis M. (2002). - Effect of temperature on the transmission of orbiviruses by the biting midge, Culicoides sonorensis. Med. Vet. Entomol., 16, 147-156.

65. Mellor P.S., Carpenter S., Harrup L., Baylis M. \& Mertens P.P.C. (2008). - Bluetongue in Europe and the Mediterranean Basin: history of occurrence prior to 2006. Prev. Vet. Med., 87, 4-20.

66. Purse B.V., Mellor P.S., Rogers D.J., Samuel A.R., Mertens P.P.C. \& Baylis M. (2005). - Climate change and the recent emergence of bluetongue in Europe. Nat. Rev. Microbiol., 3, 171-181.
67. Calistri P., Goffredo M., Caporale V. \& Meiswinkel R. (2003). - The distribution of Culicoides imicola in Italy: application and evaluation of current Mediterranean models based on climate. J. Vet. Med., B, 50 (3), 132-138. doi:10.1046/j.14390450.2003.00631.x.

68. Conte A., Giovannini A., Savini L., Goffredo M., Calistri P. \& Meiswinkel R. (2003). - The effect of climate on the presence of Culicoides imicola in Italy. J. Vet. Med., B, 50 (3), 139-147. doi:10.1046/j.1439-0450.2003.00632.x.

69. Conte A., Gilbert M. \& Goffredo M. (2009). - Eight years of entomological surveillance in Italy show no evidence of Culicoides imicola geographical range expansion. J. Appl. Ecol., $46,1332-1339$.

70. Acevedo P., Ruiz-Fons F., Estrada R., Márquez A.L., Miranda M.A., Gortázar C. \& Lucientes J. (2010). - A broad assessment of factors determining Culicoides imicola abundance: modelling the present and forecasting its future in climate change scenarios. PLoS ONE, 5 (12), el4236.

71. Mardulyn P., Goffredo M., Conte A., Hendrickx G., Meiswinkel R., Balenghien T., Sghaier S., Lohr Y. \& Gilbert M. (2013). - Climate change and the spread of vectorborne diseases: using approximate Bayesian computation to compare invasion scenarios for the bluetongue virus vector Culicoides imicola in Italy. Molec. Ecol., 22, 2456-2466.

72. Meiswinkel R., Scolamacchia F., Dik M., Mudde J., Dijkstra E., van der Ven I.J.K. \& Elbers A.R.W. (2014). - The Mondrian matrix: Culicoides prevalence and seasonal abundance during the 2006-2008 epizootic of bluetongue in the Netherlands. Med. Vet. Entomol., 28, 10-20.

73. Walther G.R., Roques A., Hulme P.E., Sykes M.T., Pysek P., Kühn I., Zobel M., Bacher S., Botta-Dukát Z., Bugmann H., Czúcz B., Dauber J., Hickler T., Jarosík V., Kenis M., Klotz S., Minchin D., Moora M., Nentwig W., Ott J., Panov V.E., Reineking B., Robinet C., Semenchenko V., Solarz W., Thuiller W., Vilà M., Vohland K. \& Settele J. (2009). - Alien species in a warmer world: risks and opportunities. Trends Ecol. Evol., 24 (12), 686-693.

74. Lomolino M.V., Riddle B.R. \& Brown J.H. (2006). Biogeography, 3rd Ed. Sinauer Associates, Sunderland, Massachusetts.

75. Becker N. (2010). - Mosquitoes and their control. SpringerVerlag, Heidelberg, Germany.

76. Verdonschot P.F.M. \& Besse-Lototskaya A.A. (2014). - Flight distance of mosquitoes (Culicidae): a metadata analysis to support the management of barrier zones around rewetted and newly constructed wetlands. Limnologica, 45, 69-79. doi:10.1016/j.limno.2013.11.002.

77. Service M.W. (1980). - Effects of wind on the behavior and distribution of mosquitoes and blackflies. Int. J. Biometeorol., 24 (4), 347-353. 
78. Service M.W. (1997). - Mosquito (Diptera: Culicidae) dispersal - the long and short of it. J. Med. Entomol., 34 (6), 579-588.

79. Haeger J.S. (1960). - Behavior preceding migration in the saltmarsh mosquito, Aedes taeniorhynchus (Wiedemann). Mosq. News, 20, 136-147.

80. Klassen W. \& Hocking B. (1964). - The influence of a deep river valley system on the dispersal of Aedes mosquitoes. Bull. Entomol. Res., 55, 289-304.

81. Horsfall W.R. (1954). - A migration of Aedes vexans Meigen. J. Econ. Entomol., 47 (3), 544.

82. Mapaco L.P., Coetzer J.A.W., Paweska J.T. \& Venter E.H. (2012). - An investigation into an outbreak of Rift Valley fever on a cattle farm in Bela-Bela, South Africa, in 2008. J. Sth Afr. Vet. Assoc., 83 (1), 132.

83. Sellers R.F., Pedgley D.E. \& Tucker M.R. (1982). - Rift Valley fever, Egypt 1977: disease spread by windborne insect vectors. Vet. Rec., 110 (4), 73-77.

84. Huang Z. \& Tatem A.J. (2013). - Global malaria connectivity through air travel. Malaria J., 12, 269.

85. Karch S., Dellile M.F., Guillet P. \& Mouchet J. (2001). - African malaria vectors in European aircraft. Lancet, 357 (9251), 235. doi:http://dx.doi.org/10.1016/S0140-6736(05)71339-8.

86. Tatem A.J., Huang Z., Das A., Qi Q., Roth J. \& Qiu Y. (2012). - Air travel and vector-borne disease movement. Parasitology, 139 (14), 1816-1830.

87. Sutcliffe J.F. (1987). - Distance orientation of biting flies to their hosts. Insect Sci. Applic., 8, 611-616.

88. Takken W. (1996). - Synthesis and future challenges: the response of mosquitoes to host odours. Olfaction Mosq.-Host Interactions, 200, 302-320.

89. Bidlingmayer W.L. (1964). - Effect of moonlight on flight activity of mosquitoes. Ecology, 45 (1), 87-94.

90. Guerra C.A., Reiner R.C., Perkins T.A., Lindsay S.W., Midega J.T., Brady O.J., Barker C.M., Reisen W.K., Harrington L.C., Takken W., Kitron U., Lloyd A.L., Hay S.I., Scott T.W. \& Smith D.L. (2014). - A global assembly of adult female mosquito mark-release-recapture data to inform the control of mosquito-borne pathogens. Parasit. Vectors, 7, 276.

91. Grassi B. (1920). - Osservazioni sulla vita degli anofeli. Atti della Accademia Nazionale dei Lincei. Rendiconti, 29, 339-344.

92. Verhulst N.O., Loonen J.A.C.M. \& Takken W. (2013). Advances in methods for colour marking of mosquitoes. Parasit. Vectors, 6, 200.

93. Sudarić Bogojević M., Merdić E. \& Bogdanović T. (2011). The flight distances of floodwater mosquitoes (Aedes vexans, Ochlerotatus sticticus and Ochlerotatus caspius) in Osijek, eastern Croatia. Biologia, 66 (4), 678-683.
94.Chen I.C., Hill J.K., Ohlemueller R., Roy D.B. \& Thomas C.D. (2011). - Rapid range shifts of species associated with high levels of climate warming. Science, 333 (6045), 1024-1026.

95. Gilman S.E., Urban M.C., Tewksbury J., Gilchrist G.W. \& Holt R.D. (2010). - A framework for community interactions under climate change. Trends Ecol. Evol., 25 (6), 325-331. doi:10.1016/j.tree.2010.03.002.

96.Juliano S.A. \& Lounibos L.P. (2005). - Ecology of invasive mosquitoes: effects on resident species and on human health. Ecol. Letters, 8 (5), 558-574.

97. Juliano S.A. (1998). - Species introduction and replacement among mosquitoes: interspecific resource competition or apparent competition? Ecology, 79 (1), 255-268.

98. Takumi K., Scholte E.J., Braks M., Reusken C., Avenell D. \& Medlock J.M. (2009). - Introduction, scenarios for establishment and seasonal activity of Aedes albopictus in the Netherlands. Vector Borne Zoonotic. Dis., 9 (2), 191-196.

99. Fischer D., Thomas S.M., Neteler M., Tjaden N.B. \& Beierkuhnlein C. (2014). - Climatic suitability of Aedes albopictus in Europe referring to climate change projections: comparison of mechanistic and correlative niche modelling approaches. Eurosurveillance, 19 (6), 34-46.

100.Phillips S.J., Anderson R.P. \& Schapire R.E. (2006). - Maximum entropy modeling of species geographic distributions. Ecol. Modell., 190 (3-4), 231-259. doi:10.1016/j.ecolmodel.2005.03.026

101. Mweya C.N., Kimera S.I., Kija J.B. \& Mboera L.E.G. (2013). - Predicting distribution of Aedes aegypti and Culex pipiens complex, potential vectors of Rift Valley fever virus in relation to disease epidemics in East Africa. Infect. Ecol. Epidemiol., 3, 21748.

102. Hill M.P., Axford J.K. \& Hoffmann A.A. (2014). - Predicting the spread of Aedes albopictus in Australia under current and future climates: multiple approaches and datasets to incorporate potential evolutionary divergence. Aust. Ecol., 39, 469-478.

103. Tonnang H.E., Kangalawe R.Y. \& Yanda P.Z. (2010). Predicting and mapping malaria under climate change scenarios: the potential redistribution of malaria vectors in Africa. Malaria J., 9, 111.

104. Saikkonen K., Taulavuori K., Hyvönen T., Gundel P.E., Hamilton C.E., Vänninen I., Nissinen A. \& Helander M. (2012). - Climate change-driven species' range shifts filtered by photoperiodism. Nature Climate Change, 2 (4), 239-242.

105. Chaves L.F. \& Koenraadt C.J.M. (2010). - Climate change and highland malaria: fresh air for a hot debate. 2. Rev. Biol., 85 (1), 27-55. 
106.Paaijmans K.P., Read A.F. \& Thomas M.B. (2009). Understanding the link between malaria risk and climate. Proc. Natl Acad. Sci. USA, 106 (33), 13844-13849.

107. Koenraadt C.J.M. \& Harrington L.C. (2008). - Flushing effect of rain on container-inhabiting mosquitoes Aedes aegypti and Culex pipiens (Diptera : Culicidae). J. Med. Entomol., 45 (1), 28-35.
108.Shaman J. \& Day J.F. (2005). - Achieving operational hydrologic monitoring of mosquitoborne disease. Emerg. Infect. Dis., 11 (9), 1343-1350. doi:10.3201/ eid1109.050340.

109. Bicout D.J. \& Sabatier P. (2004). - Mapping Rift Valley fever vectors and prevalence using rainfall variations. Vector Borne Zoonotic Dis., 4 (1), 33-42. 
